\title{
Chronic Arsenic Exposure through Drinking Water and Risk of Type 2 Diabetes Mellitus: A Study from Bangladesh
}

\author{
MK NESHA ${ }^{\mathrm{a}}$, MN ISLAM $^{\mathrm{b}}, \mathrm{N} \mathrm{FERDOUS}^{\mathrm{c}}$, FB NAZRUL $^{\mathrm{d}}, \mathrm{JJ}^{\mathrm{R}}$ RASKER $^{\mathrm{e}}$
}

\begin{abstract}
Summery:
The well-documented fact that chronic arsenic exposure can lead to skin lesions, atherosclerotic diseases and cancers. The findings of association between arsenic exposure and diabetes mellitus indicate additional risk to human health.

The aim of this study was to observe the association of chronic arsenic exposure from drinking water and risk of development of type 2 diabetes mellitus. To this end, a cross-sectional study was conducted in Comilla district of Bangladesh where ground water is heavily contaminated with arsenic. The individuals unexposed to arsenic were recruited from the Jhenaidah district. People with arsenic-related skin lesions were defined as subjects exposed to arsenic. Diabetes was defined if fasting blood glucose (FBG)>6.1 mmol/L following World Health Organization (WHO) guidelines.
\end{abstract}

Introduction:

The contamination of groundwater with arsenic (As) is a big threat in various countries including Argentina, Australia, Bangladesh, Chile, China, Hungary, India, Mexico, Peru, Taiwan, and the United States of America. According to U.S. Environmental Protection Agency (USEPA) from 2001, the acceptable level of arsenic in drinking water is $10 \mathrm{ppb}$, though for many years the value was 50 parts per billion (ppb, equivalent to 50 micrograms per liter) ${ }^{1}$. However, the worst case scenario

a. Mst Karimon Nesha, MSc Student, Department of GIS and Earth Observation for Natural Resources Management, University of Twente, The Netherlands.

b. Prof. Md. Nazrul Islam, Professor of Rheumatology, Department of Rheumatology, Bangabandhu Sheikh Mujib Medical University, Dhaka.

c. Dr. Nira Ferdous, Assistant Professor, Department of Medicine, MH Samorita Medical College, Tajgaon, Dhaka.

d. Dr. Fahid Bin Nazrul, Medical Office and Research Coordinator, Modern One Stop Arthritis Care \& Research Center ${ }^{\circledR}$ (MOAC\&RC®), House 17, Dhanmondi, Road 8, Dhaka.

e. Prof. Johannes J Rasker, Faculty of Behavoural Sciences, Department of Psychology, Health \& Technology, University of Twente, Enschede, The Netherlands.

Address of Correspondence: Prof. Md. Nazrul Islam, Professor of Rheumatology, Department of Rheumatology, Room No 1605, Level 16, D Block, Bangabandhu Sheikh Mujib Medical University, Dhaka. Mobile: 01678112396,Email: islam1nazrul@gmail.com

Received: 12 November, 2017

Accepted: 4 September, 2018
The common odds ratio for diabetes mellitus among subjects exposed to arsenic was 3.5 (95\% confidence interval 1.1-10.9). After adjustment for age, sex and BMI, the Mantel-Haenszel weighted prevalence ratio was 3.5 (95\% CI: 1.1-11.1); 3.7 (95\% CI: 1.1-11.8) and 4.4 (95\% CI: 1.1-17.2) respectively. The indicated relationships were significant $(P<0.05)$.

The observations suggested, chronic arsenic exposure through drinking water may be a risk factor of type 2 diabetes mellitus.

Key Words: Arsenic, Drinking water, Diabetes mellitus, Bangladesh

(J Bangladesh Coll Phys Surg 2019; 37: 5-12)

DOI: http://dx.doi.org/10.3329/jbcps.v37i1.39281

has been reported in Bangladesh and West Bengal of India ${ }^{2}$. Approximately $56 \%$ of the tube wells (out of $34,000)$ throughout Bangladesh contain Arsenic more than $101 / 4 \mathrm{~g} / \mathrm{L}$ and some $37 \%$ have greater than $501 / 4 \mathrm{~g} /$ $\mathrm{L}^{3}$. It has been estimated that about 50 million people in Bangladesh are chronically exposed to arsenic through drinking water ${ }^{4-6}$. Public health problems related to chronic arsenic exposure through drinking water have been linked to increased risks of skin cancer ${ }^{7}$ bladder, lung, and liver cancers ${ }^{8,9}$ as well as cardiovascular diseases ${ }^{10,11}$. In further, arsenic exposure has been suggested to be associated with development of diabetes mellitus as well ${ }^{12}$. Another cohort study from Taiwan reported that a long-term exposure to arsenic is associated with diabetes mellitus in humans ${ }^{13}$. Similar report (inorganic arsenic exposure may be diabetogenic) was also from the state of Coahuila, Mexico ${ }^{14}$. More recently, a cross-sectional study from National Health and Nutrition Examination Survey (NHANES) reported that the OR for diabetes was $3.6(95 \%$ CI, $1.2-10.8)$ when they compared par-ticipants at the 80th percentile with those at the 20th percentile for urinary arsenic ${ }^{15}$. As far as Bangladesh is concerned, a dose-response relationship between prevalence of diabetes mellitus and exposure to arsenic through drinking water was reported only a few studies ${ }^{16,17}$.

Not only drinking water exposure, several studies had reported occupational chronic arsenic exposures 
association with diabetes mellitus. For example, Swedish copper smelter workers revealed an increased risk of dying from diabetes mellitus with increasing arsenic exposure as compared to an unexposed control group ${ }^{18}$. In another study on Swedish art glass workers, the odds ratio of dying from diabetes mellitus was 1.8 for the exposed glass workers compared to unexposed ones ${ }^{19}$. Occupational exposure to arsenic was associated significantly with an increased level of glycosylated hemoglobin in Denmark ${ }^{20}$. Other studies had shown an increased morbidity and mortality of diabetic patients having exposed to arsenic at work when compared with general population or unexposed workers ${ }^{18,19,21,22}$.

However, in contrary, many studies opposed such association between chronic arsenic exposure and diabetes mellitus. For instance, no significant association was observed in a community-based studies in areas of low arsenic exposure in the $\mathrm{USA}^{23,24}$. A study from Bangladesh in 2010 has reported that there is no association of chronic arsenic exposure, to diabetes, glycosuria, or blood $\mathrm{HbAlc}$ level ${ }^{25}$. Similarly, a couple of studies also reported no association of occupational arsenic exposures with increase mortality of diabetes mellitus in arsenic-exposed workers than the general population ${ }^{26-29}$.

The aim of this study was to observe the possible association between chronic arsenic exposure and type 2 diabetes mellitus in areas of Bangladesh taking into account demographic, social and medical risk factors.

\section{Methods:}

This cross-sectional study was conducted in 4 villages viz. Eruen, Madhaya Eruen, Rajapur and Nagrapa from Lacksam Upazila of Comilla district as these areas have high arsenic levels in sources of drinking water. These locations were selected based on the Bangladesh arsenic Mitigation Water Supply Project's (BAMWSP) national survey report. The arsenic concentration of artesian well water in these villages ranged from 0.07 to $1.4 \mathrm{ppm}$ with a mean concentration of $0.15 \mathrm{ppm}$. The standard for arsenic in drinking water set by the U.S. Environmental Protection Agency is $0.05 \mathrm{mg} / \mathrm{L}$ for Bangladesh ${ }^{9}$. As reference population we arbitrarily recruited unexposed individuals through a door-to-door visit from a village, Vespara, from Kaliganj Upazila of Jhenaidah district. The population of Jhenaidah is not known to be exposed to arsenic through drinking water, which is provided from the Water and Sewage Agency, Bangladesh.

A total of 150 subjects chronically exposed to arseniccontaminated drinking water were recruited randomly from those who have skin manifestations such as keratosis, leucomelanosis and melanosis as skin lesions are a marker of pro-longed arsenic exposure. The lesions in skin were confirmed by the physicians of local health centre. The unexposed age ( $\geq 30$ years) and sex matched reference population of 150 individuals were recruited from control area. One and 2 subjects with family history of hypertension in the exposed and non-exposed groups respectively were excluded. Three subjects in the exposed group and 1 subject in the non-exposed group was denied to participate in the study.

A semi-structured questionnaire was used to obtain information on socioeconomic, demographic characteristics, history of arsenic contaminated water consumption, height, weight, alcohol intake, cigarette smoking, physical activities, as well as personal, family history of hypertension and diabetes. The arsenic content of tube well water was taken from the report of BAMWSP survey. Type 2 diabetes was screened by a Glucometer. Diagnosis of DM was defined using the diagnostic criteria (FBG $>6.1 \mathrm{mmol} / \mathrm{L}$ ) from the $\mathrm{WHO}$ guidelines.

\section{Statistics}

The data were stratified according to age (30-44, 4559 , and $>60$ years), sex, and body mass index (BMI); the BMI categories were less than 19, 19-22, and $>22$. Mantel-Haenszel weighted prevalence ratios (MH-PR) with 95 percent confidence intervals were calculated to determine the association of chronic arsenic exposure with type 2 diabetes mellitus. All the potential confounders were adjusted during the analysis.

\section{Ethics}

The study was approved by Khulna University, Khulna, Bangladesh as part of the graduation study. The study was performed following the Declaration of Helsinki principles and informed consent was given by all participants before enrolment.

\section{Results:}

This study was carried out in areas of high arsenic contamination in drinking water and compared with areas not containing arsenic in drinking water. The mean age of the As exposed group was 45.5 years and 45.7 in the reference group. Male and female participants in the exposure group were $26 \%$ and $74 \%$ respectively, and in the reference group, it was $30 \%$ and $70 \%$ respectively. The major occupations in the exposed group were housewife (74\%) and farmer (12\%) and in the reference group, the main occupations were also housewife (69\%) and farmer (12\%. In the As exposed group, the age of most of the participants (53\%) ranged 
from 30 to 44 years. This figure for ages between 30 and 44 in comparison group accounted for $51 \%$. Subjects aging between 45 to 60 years were $35 \%$ and $37 \%$ in the exposed group and the comparison group respectively. In the As group, $74 \%$ had no formal education and in the control group, the corresponding figure was $70 \%$. The comparison of sociodemographic characteristics between As exposed group and comparison group are presented in table 1 .

The BMI in the As exposed group was lower than in control group (Table 1). The history of alcohol intake, cigarette smoking, physical activities, as well as personal and family history of hypertension and diabetes in the family in the AS exposed group was comparable with that in the control group (Table 1)

Table-I

\begin{tabular}{|c|c|c|c|c|}
\hline \multicolumn{5}{|c|}{$\begin{array}{c}\text { Socio-demographic characteristics of participants exposed and not exposed } \\
\text { to arsenic through drinking water }(n=300)\end{array}$} \\
\hline \multirow[t]{2}{*}{ Variables } & \multicolumn{2}{|c|}{ Exposed group $(n=150)$} & \multicolumn{2}{|c|}{ Not exposed group $(n=150)$} \\
\hline & No & $(\%)$ & No. & $(\%)$ \\
\hline \multicolumn{5}{|l|}{ Age (years) } \\
\hline $30-44$ & 80 & 53.3 & 76 & 50.7 \\
\hline $45-60$ & 53 & 35.3 & 56 & 37.3 \\
\hline$>60$ & 17 & 11.3 & 18 & 12 \\
\hline \multicolumn{5}{|l|}{ Sex } \\
\hline Male & 39 & 26 & 45 & 30 \\
\hline Female & 111 & 74 & 105 & 70 \\
\hline \multicolumn{5}{|l|}{ Occupation } \\
\hline Cultivator & 18 & 12 & 17 & 11.3 \\
\hline Day labor & 5 & 3.3 & 11 & 7.3 \\
\hline House wife & 111 & 74 & 103 & 68.7 \\
\hline Business & 7 & 4.7 & 15 & 10 \\
\hline Service & 6 & 4 & 2 & 1.3 \\
\hline *Others & 3 & 0.21 & 2 & 1.3 \\
\hline \multicolumn{5}{|l|}{ Education } \\
\hline No formal Education & 111 & 74 & 105 & 70 \\
\hline Primary School & 21 & 14 & 17 & 11.3 \\
\hline High School & 12 & 8 & 21 & 14 \\
\hline SSC & 5 & 3.3 & 4 & 2.7 \\
\hline HSC & 1 & 0.7 & 3 & 2 \\
\hline \multicolumn{5}{|l|}{ Religion } \\
\hline Islam & 147 & 98 & 52 & 34.7 \\
\hline Hinduism & 3 & 2 & 98 & 65.3 \\
\hline \multicolumn{5}{|l|}{ Marital Status } \\
\hline Married & 134 & 89.3 & 130 & 86.7 \\
\hline Widowed & 14 & 9.3 & 20 & 13.3 \\
\hline Divorced & 1 & 0.7 & 0 & \\
\hline Never Married & 1 & 0.7 & 0 & \\
\hline \multicolumn{5}{|c|}{ Body Mass Index (BMI) } \\
\hline$<19$ & 90 & 60 & 33 & 22 \\
\hline $19-22$ & 36 & 24 & 51 & 34 \\
\hline$>22$ & 24 & 16 & 66 & 44 \\
\hline \multicolumn{5}{|l|}{ Physical Activities } \\
\hline Light & 40 & 26.6 & 38 & 25.3 \\
\hline Moderate & 79 & 52.6 & 73 & 48.6 \\
\hline Vigorous & 31 & 20.6 & 39 & 20 \\
\hline Alcohol Intake & 0 & 0 & 0 & 0 \\
\hline Cigarette Smoking & 17 & 11.3 & 14 & 9.3 \\
\hline
\end{tabular}

* Others $=$ Rickshaw puller, member, tuition 
Diabetes mellitus was diagnosed in 13 individuals among the As exposed subjects and in 4 persons among the subjects who drank arsenic free water. The crude prevalence ratio for diabetes mellitus was 3.5 (95\% CI, 1.1-10.9) stating that the probability for developing diabetes mellitus exposed to As contaminated water is 3.5 times higher than that for an unexposed individual (Table 2).

In order to find out a precise association between chronic arsenic exposure and diabetes mellitus, the effects of potential confounding factors viz. Age, Sex and BMI were adjusted. After adjusting for age (Table 3), the Mantel-Haenszel weighted prevalence ratio (MH-PR) was 3.5 (95\% CI: 1.1-11.1, $\mathrm{p}=0.031$ ).

With adjustment for sex, MH-PR was 3.7 (95\%CI: 1.1-11.8, $\mathrm{p}=0.029$ ) (Table 4).When adjusted for BMI, MH-PR increased to 4.4 (95\% CI: 1.1 - 17.2) $\mathrm{p}=0.032$ (Table 5).

Table-II

Type 2 Diabetes in exposed and not exposed to arsenic through drinking water $(n=300)$

Arsenic exposure

Diabetes

\begin{tabular}{lccc} 
& Diabetic & Non diabetic & Total \\
\hline Exposed & $13(8.7 \%)$ & $137(91.3 \%)$ & $150(100 \%)$ \\
Not exposed & $4(2.7 \%)$ & $146(97.3 \%)$ & $150(100 \%)$ \\
\hline Total & $17(5.7 \%)$ & $283(94.3 \%)$ & $300(100 \%)$ \\
\hline Fisher's Exact Test & 0.043 & & \\
Mantel-Haenszel Common Odds Ratio & 3.5 & & \\
95\% Confidence Interval & $1.1-10.9$ & &
\end{tabular}

Table-III

According to age, type 2 diabetes mellitus in exposed and not exposed to arsenic through drinking water $(n=300)$

\begin{tabular}{llccc}
\multirow{2}{*}{ Age } & Arsenic exposure & \multicolumn{3}{c}{ Diabetic status } \\
\cline { 3 - 5 } & & Diabetic & Not diabetic & Total \\
\hline $30-44$ & Exposed & $5(6.2 \%)$ & $75(93.8 \%)$ & $80(100 \%)$ \\
& Not exposed & $1(1.3 \%)$ & $75(98.7 \%)$ & $76(100 \%)$ \\
Total & $6(3.8 \%)$ & $150(96.2 \%)$ & $156(100 \%)$ & \\
$45-60$ & Exposed & $5(9.4 \%)$ & $48(90.6 \%)$ & $53(100 \%)$ \\
& Not exposed & $3(5.4 \%)$ & $53(94.6 \%)$ & $56(100 \%)$ \\
Total & $8(7.3 \%)$ & $101(92.7 \%)$ & $109(100 \%)$ & $17(100 \%)$ \\
$>60$ & Exposed & $3(17.6 \%)$ & $14(82.4 \%)$ & $18(100 \%)$ \\
& Not exposed & $0(0 \%)$ & $18(100 \%)$ & \\
\hline Total & $3(8.6 \%)$ & $32(91.4 \%)$ & $35(100 \%)$ & \\
\hline Mantel-Haenszel Common Odds Ratio & 3.5 & & \\
Exact Sig. (2-sided) & 0.031 & & \\
$95 \%$ Confidence Interval & $1.1-11.1$ & &
\end{tabular}


Table-IV

\section{According to sex, type 2 diabetes mellitus in exposed and not exposed} to arsenic through drinking water $(n=300)$

\begin{tabular}{llccc} 
Sex & Arsenic exposure & Diabetic & Non diabetic & Total \\
\hline Male & Exposed & $4(10.3 \%)$ & $35(89.7 \%)$ & $39(100 \%)$ \\
& Not exposed & $3(6.7 \%)$ & $42(93.3 \%)$ & $45(100 \%)$ \\
Total & $7(8.3 \%)$ & $77(91.7 \%)$ & $84(100 \%)$ & \\
Female & Exposed & $9(8.1 \%)$ & $102(91.9 \%)$ & $111(100 \%)$ \\
& Not exposed & $1(1.0 \%)$ & $104(99.0 \%)$ & $105(100 \%)$ \\
\hline Total & $10(4.6 \%)$ & $206(95.4 \%)$ & $216(100 \%)$ & \\
\hline Mantel-Haenszel Common Odds Ratio & 3.7 & & \\
Exact Sig. (2-sided) & 0.029 & & \\
95\% Confidence Interval & $1.1-11.8$ & &
\end{tabular}

Table-V

According to BMI, type 2 diabetes mellitus in exposed and not exposed to arsenic through drinking water $(n=300)$

\begin{tabular}{|c|c|c|c|c|}
\hline BMI & Arsenic exposure & Diabetic & Non diabetic & Total \\
\hline \multirow[t]{2}{*}{$<19$} & Exposed & $9(10 \%)$ & $81(90 \%)$ & $90(100 \%)$ \\
\hline & Not exposed & $0(0 \%)$ & $33(100 \%)$ & $33(100 \%)$ \\
\hline Total & $9(7.3 \%)$ & $114(92.7 \%)$ & $123(100 \%)$ & \\
\hline \multirow[t]{2}{*}{$19-22$} & Exposed & $2(5.6 \%)$ & $34(94.4 \%)$ & $36(100 \%)$ \\
\hline & Not exposed & $1(2 \%)$ & $50(98 \%)$ & $51(100 \%)$ \\
\hline Total & $3(3.4 \%)$ & $84(96.6 \%)$ & $87(100 \%)$ & \\
\hline \multirow[t]{2}{*}{$>22$} & Exposed & $2(8.3 \%)$ & $22(91.7 \%)$ & $24(100 \%)$ \\
\hline & Not exposed & $3(4.5 \%)$ & $63(95.5 \%)$ & $66(100 \%)$ \\
\hline Total & $5(5.6 \%)$ & $85(94.4 \%)$ & $90(100 \%)$ & \\
\hline \multicolumn{2}{|c|}{ Mantel-Haenszel Common Odds Ratio } & 4.4 & & \\
\hline \multicolumn{2}{|c|}{ Exact Sig. (2-sided) } & 0.032 & & \\
\hline \multicolumn{2}{|c|}{$95 \%$ Confidence Interval } & $1.1-17.2$ & & \\
\hline
\end{tabular}

\section{Discussion}

The results of this study support the association between a long-term arsenic exposure and diabetes mellitus, as observed by other investigators ${ }^{12,13,16,18,19}$.

Exposure to inorganic arsenic, as indicated by animal and in vitro model systems, can potentially increase the risk of developing diabetes through its implications on the inhibition of insulin-dependent glu-cose uptake $^{30}$, insulin signaling ${ }^{31}$, impairment of insulin secretion, transcription in pancre-atic beta cells $\mathrm{s}^{32}$ and modification of the expression of genes involved in insulin resistance ${ }^{33}$. However, the concentrations of arsenic in most of these experiments are high, and the resulting effects may not be pertinent to populations chronically exposed to arsenic in the environment.

Nevertheless, the epide-miologic literature suggests that diabetes is an adverse outcome associated with prolonged exposure to high levels of arsenic ( $>500$ $\mu \mathrm{g} / \mathrm{L})$ in drinking water ${ }^{17}$. Among patients with skin lesions, a marker of pro-longed exposure, the OR for diabetes in associ-ation with 500-1,000 $\mu \mathrm{g} / \mathrm{L}$ and $>1,000 \mu \mathrm{g} / \mathrm{L}$ was 2.2 and 2.6 respectively ${ }^{17}$. In a cohort study in southwestern Taiwan, the OR of diabetes was 2.1 comparing individuals with cumulative arsenic exposure $>17,000 \mu \mathrm{g} / \mathrm{L}$-years to those with $<17,000$ $\mu \mathrm{g} / \mathrm{L}-$ years ${ }^{13}$. 
On the other hand, the relation between inorganic arsenic exposure and diabetes mellitus has been reported yet to be inconclusive particularly at low to moderate levels of exposure to arsenic ${ }^{34}$. Even no evidence of an association was found in a study in Bangladesh where $90 \%$ of study population was exposed to well water arsenic $<300 \mu \mathrm{g} / \mathrm{L}$ when comparing the highest level of exposure (176-864 $\mu \mathrm{g} /$ $\mathrm{L}$; mean, $291.2 \mu \mathrm{g} / \mathrm{L})$ with the lowest $(0.1-8 \mu \mathrm{g} / \mathrm{L}$; mean, $2.4 \mu \mathrm{g} / \mathrm{L}$ ). Therefore, this study suggests that arsenic exposure between 10 and $300 \mu \mathrm{g} / \mathrm{L}$ is not significant to pose a risk of diabetes ${ }^{25}$.

Occupational studies have also been inconclusive. While in the studies at a copper smelter ${ }^{18}$ and an art glass industry ${ }^{19}$ in Sweden, an association between occupational arsenic exposure and diabetes has been reported, no relation has been observed in a US copper smelter ${ }^{26}$ and in a UK tin smelter ${ }^{35}$. The experimental and epidemiologic evidence suggest that the adverse effects on diabetes may be dose specific and limited to populations with prolonged exposure to very high levels of arsenic exposure.

One of the main problems of published epidemiological studies is related to measurement errors. In several of the studies only glycosuria as a diagnosis of the disease was used ${ }^{16,17}$ or statistical records ${ }^{36-39}$. Only a couple of studies used glucose measurement after an oral glucose tolerance test ${ }^{12,13}$ but in one of them the comparison group was not studied concurrently with the exposed group ${ }^{13}$. In our study, glucose measurement after an oral glucose tolerance test was used to diagnose diabetes as advised by WHO.

Deficiencies of trace elements such as copper and zinc have been suggested to play a role in the pathogenesis of diabetes mellitus ${ }^{40}$; administration of cadmium has been shown also to cause hyperglycemia ${ }^{41}$. Arsenic has been reported to interact with these chemicals. Arsenic exposure can lead to a significant increase in renal copper excretion and can potentiate the effects of cadmium when arsenic and cadmium are used together ${ }^{42}$. Arsenic may also compete with zinc in metal-binding proteins that display vicinal dithiols contained in zinc fingers of DNA binding and repair proteins. This competitive binding causes conformational change and altered biological function in proteins ${ }^{43}$. However, it is not known whether these elements or other toxic trace elements are present in groundwater in the study area.

In this study all subjects were recruited from rural villages of almost similar occupation, socioeconomic status, and lifestyle. These variables were reasonably similar between exposed and unexposed people and it was, therefore, unlikely to influence glycosuria either in the presence or absence of skin lesions. The controls had higher BMI than As exposed people, despite that they had less frequently diabetes. A low body mass may be ascribed to the effect of As.

A weakness of the study is that we have no long term follow up of our cases.

Strength of the study is the availability of data on environmental exposure to arsenic. Unlike previous studies of lower-level arsenic exposure ${ }^{15,23,24}$, this study popu-lation was well described with detailed data on the duration, source, and form of expo-sure. Another strength is that we have taken into account social and clinical risk factors as well as other risk factors like alcohol intake, cigarette smoking, physical activities, as well as personal and family history of hypertension and diabetes.

\section{Conclusions:}

Chronic arsenic exposure in drinking water may be a risk factor for type 2 diabetes mellitus.

\section{Acknowledgements:}

We thanked all participants and the local health centers for their cooperation.

\section{References:}

1. WHO. Arsenic in drinking water. Fact sheet 210. May; 2001.

2. Roychowdhury T. Impact of sedimentary arsenic through irrigated groundwater on soil, plant, crops and human continuum from Bengal delta: special reference to raw and cooked rice. Food and chemical toxicology. 2008;46(8):2856-64.

3. Chakraborti D, Sengupta MK, Rahman MM, Chowdhury UK, Lodh D, Chanda CR, et al. Groundwater arsenic exposure in India. the book â॰ ${ }^{\sim}$ Arsenic Exposure and Health Effectsâ•TM, Edited by WR Chappell, CO Abernathy, RL Calderon Publisher: Elsevier science, Amsterdam-Lausanne-New York-Oxford-Tokyo. 2003:3-24.

4. BGS-DPHE. Groundwater Studies for Arsenic Contamination in Bangladesh.Final Report.Mott MacDonald Ltd, British Geological Survey, London, UK. 1999.

5. EPA US. Arsenic Occurance in Public Drinking Water Supplies.EPA-815-R-00-023. 2000.

6. EPA US. Fact Sheet about the January 2001 Arsenic Rule.EPA 815-F-00-015. 2001.

7. Hsueh Y-M, Chiou H-Y, Huang Y-L, Wu W-L, Huang C-C, Yang $\mathrm{M}-\mathrm{H}$, et al. Serum beta-carotene level, arsenic methylation capability, and incidence of skin cancer. Cancer Epidemiology Biomarkers \& Prevention. 1997;6(8):589-96. 
8. Chen C-J, Kuo T-L, Wu M-M. Arsenic and cancers. The Lancet. 1988;331(8582):414-5.

9. Chen Y,Ahsan H, Parvez F, Howe GR. Validity of a food-frequency questionnaire for a large prospective cohort study in Bangladesh. British Journal of Nutrition. 2004;92(05):851-9.

10. Chen C-J, Chiou H-Y, Chiang M-H, Lin L-J, Tai T-Y. Doseresponse relationship between ischemic heart disease mortality and long-term arsenic exposure.Arteriosclerosis, thrombosis, and vascular biology. 1996;16(4):504-10.

11. Chen C-J, Hsueh Y-M, Lai M-S, Shyu M-P, Chen S-Y, Wu M-M, et al. Increased prevalence of hypertension and long-term arsenic exposure. Hypertension. 1995;25(1):53-60.

12. Lai M-S, Hsueh Y-M, Chen C-J, Shyu M-P, Chen S-Y, Kuo T-L, et al. Ingested inorganic arsenic and prevalence of diabetes mellitus. American Journal of Epidemiology. 1994;139(5):484-92.

13. Tseng C-H, Tai T-Y, Chong C-K, Tseng C-P, Lai M-S, Lin BJ, et al. Long-term arsenic exposure and incidence of non-insulindependent diabetes mellitus: a cohort study in arseniasishyperendemic villages in Taiwan. Environmental Health Perspectives. 2000:847-51.

14. Coronado-Gonz $\tilde{i}_{i}$ lez JA, Del Razo LMa, Garc ̃̃-a-Vargas G, Sanmiguel-Salazar F, Escobedo-de la Pe $\tilde{A} \pm$ J J. Inorganic arsenic exposure and type 2 diabetes mellitus in Mexico. Environmental research. 2007;104(3):383-9.

15. Navas-Acien A, Silbergeld EK, Pastor-Barriuso R, Guallar E. Arsenic exposure and prevalence of type 2 diabetes in US adults. JAMA: the journal of the American Medical Association. 2008;300(7):814-22.

16. Rahman M, Tondel M, Ahmad SA, Axelson O. Diabetes mellitus associated with arsenic exposure in Bangladesh. American Journal of Epidemiology. 1998;148(2):198-203.

17. Rahman M, Tondel M, Chowdhury IA, Axelson O. Relations between exposure to arsenic, skin lesions, and glucosuria. Occupational and environmental medicine. 1999;56(4):277-81.

18. Rahman M, Axelson O. Diabetes mellitus and arsenic exposure: a second look at case-control data from a Swedish copper smelter. Occupational and environmental medicine. 1995;52(11):773-4.

19. Rahman M, Wingren G, Axelson O. Diabetes mellitus among Swedish art glass workersâ•"an effect of arsenic exposure? Scandinavian journal of work, environment \& health. 1996: 146-9.

20. Jensen GE, Hansen ML. Occupational arsenic exposure and glycosylated haemoglobinâ• Analyst. 1998;123(1):77-80.

21. Lagerkvist BJ, Zetterlund B. Assessment of exposure to arsenic among smelter workers: A fiveâ••year followâ••up. American journal of industrial medicine. 1994;25(4):477-88.

22. Tollestrup K, Frost FJ, Harter LC, McMillan GP. Mortality among children residing near the American Smelting and Refining Company (ASARCO) copper smelter in Ruston, Washington. Archives of Environmental Health: An International Journal. 2003;58(11):683-91.
23. Lewis DR, Southwick JW, Ouellet-Hellstrom R, Rench J, Calderon RL. Drinking water arsenic in Utah: A cohort mortality study. Environmental Health Perspectives. 1999;107(5):359.

24. Zierold KM, Knobeloch L, Anderson H. Prevalence of chronic diseases in adults exposed to arsenic-contaminated drinking water. Journal Information. 2004;94(11).

25. Chen Y, Ahsan H, Slavkovich V, Peltier GL, Gluskin RT, Parvez F, et al. No association between arsenic exposure from drinking water and diabetes mellitus: a cross-sectional study in Bangladesh. Environmental Health Perspectives. 2010; 118(9):1299.

26. Lubin JH, Pottern LM, Stone BJ, Fraumeni JF. Respiratory cancer in a cohort of copper smelter workers: results from more than 50 years of follow-up. American Journal of Epidemiology. 2000;151(6):554-65.

27. Bartoli D, Battista G, De Santis M, Iaia TE, Orsi D, Tarchi M, et al. Cohort study of art glass workers in Tuscany, Italy: mortality from non-malignant diseases. Occupational Medicine. 1998;48(7):441-5.

28. Enterline PE, Marsh GM. Cancer among workers exposed to arsenic and other substances in a copper smelter. American Journal of Epidemiology. 1982;116(6):895-911.

29. Mabuchi K, Lilienfeld AM, Snell LM. Cancer and occupational exposure to arsenic: a study of pesticide workers. Preventive medicine. 1980;9(1):51-77.

30. Walton FS, Harmon AW, Paul DS, DrobnÃ ; Z, Patel YM, Styblo M. Inhibition of insulin-dependent glucose uptake by trivalent arsenicals: possible mechanism of arsenic-induced diabetes. Toxicology and applied pharmacology. 2004;198(3):424-33.

31. Paul DS, Harmon AW, Devesa V, Thomas DJ, St $\tilde{A}^{1} / 2$ blo M. Molecular mechanisms of the diabetogenic effects of arsenic: inhibition of insulin signaling by arsenite and methylarsonous acid. Environmental Health Perspectives. 2007;115(5):734.

32. Diaz-Villasenor A, Sanchez-Soto MC, Cebrian ME, OstroskyWegman P, Hiriart M. Sodium arsenite impairs insulin secretion and transcription in pancreatic $\hat{I}^{2}$-cells. Toxicology and applied pharmacology. 2006;214(1):30-4.

33. Diaz-Villasenor A, Burns AL, Hiriart M, Cebrian ME, OstroskyWegman P. Arsenic-induced alteration in the expression of genes related to type 2 diabetes mellitus. Toxicology and applied pharmacology. 2007;225(2):123-33.

34. Navas-Acien A, Silbergeld EK, Streeter RA, Clark JM, Burke TA, Guallar E. Arsenic exposure and type 2 diabetes: a systematic review of the experimental and epidemiologic evidence. Environmental Health Perspectives. 2006;114(5):641.

35. Binks K, Doll R, Gillies M, Holroyd C, Jones SR, McGeoghegan D, et al. Mortality experience of male workers at a UK tin smelter. Occupational Medicine. 2005;55(3):215-26.

36. Chiu H-F, Chang C-C, Tsai S-S, Yang C-Y. Does arsenic exposure increase the risk for diabetes mellitus? Journal of occupational and environmental medicine. 2006;48(1):63-7. 
37. Tsai S-M, Wang T-N, Ko Y-C. Mortality for certain diseases in areas with high levels of arsenic in drinking water. Archives of Environmental Health: An International Journal. 1999;54(3):18693.

38. Wang S-L, Chiou J-M, Chen C-J, Tseng C-H, Chou W-L, Wang $\mathrm{C}-\mathrm{C}$, et al. Prevalence of non-insulin-dependent diabetes mellitus and related vascular diseases in southwestern arseniasisendemic and nonendemic areas in Taiwan. Environmental Health Perspectives. 2003;111(2):155.

39. Wang SL, Chou WL, Wang CC, Chen CJ. Cardiovascular Disease Profile and Its Relation to Diabetes in Arseniasis-Endemic Area in Southwestern Taiwan: Isee-388. Epidemiology. 2003;14(5):S77.
40. Group WHOS. Report of diabetes mellitus technical report series. No 727. World Health Organisation Geneva. 1985.

41. Bell RR, Early JL, Nonavinakere VK, Mallory Z. Effect of cadmium on blood glucose level in the rat. Toxicology letters. 1990;54(2):199-205.

42. Mahaffey KR, Capar SG, Gladen BC, Fowler BA. Concurrent exposure to lead, cadmium, and arsenic. Effects on toxicity and tissue metal concentrations in the rat. The Journal of laboratory and clinical medicine. 1981;98(4):463-81.

43. Engel RR, Hopenhayn-Rich C, Receveur O, Smith AH. Vascular effects of chronic arsenic exposure: a review. Epidemiologic reviews. 1994;16(2):184-209. 